\title{
Signifikansi Wakaf dalam Keuangan Negara: Tinjauan Ekonomi Klasik dan Kontemporer
}

\author{
Anisa Husna Adinta \\ Universitas Pembangunan Nasional Veteran Jakarta \\ anisadinta@yahoo.com \\ Muhammad Rizky Taufiq Nur \\ Universitas Pembangunan Nasional Veteran Jakarta \\ mrizkytaufiqnur@yahoo.com
}

Received: August 6, 2020 | Accepted: August 8, 2020 | Published: August 10, 2020

\begin{abstract}
Waqf is an Islamic social financial instrument that plays an important role in development. The potential of waqf that Indonesia currently has is very large. It is necessary to optimize the management of waqf so that it can be developed as a development financing instrument, as has been practiced by the Prophet Muhammad and his friends. This article aims to examine the significance of the role and contribution of waqf to the economy, regarding classical and contemporary practices. This study is a theoretical study that examines concepts and theories related to waqf from the classical era to the contemporary era. This study found that waqf has great urgency and significance for development. Waqf is also a social financial instrument with direct implications for the economy. These implications are both short and long term. From these findings, it is recommended for waqf Nazhirs to develop more optimal management of waqf in providing benefits and benefits to the wider community. Besides, it is also recommended that the Government play a role in encouraging the development of national waqf management so that the development of waqf can grow and contribute actively to the national economy. So that it can realize the welfare of society in a just and sustainable manner.
\end{abstract}

Keywords: Waqf; Social Finance; Economy; Nation

\begin{abstract}
Abstrak
Wakaf merupakan instrumen keuangan sosial Islam yang berperan penting dalam pembangunan. Potensi wakaf yang dimiliki Indonesia saat ini terbilang sangat besar. Perlu optimalisasi pengelolaan wakaf untuk dapat dikembangkan sebagai instrumen pembiayaan pembangunan, sebagaimana yang telah dipraktekkan oleh Rasulullah SAW serta para sahabatnya. Artikel bertujuan mengkaji signifikansi peran dan kontribusi wakaf terhadap perekonomian, dengan mengacu pada praktek klasik dan kontemporer. Kajian ini merupakan kajian teoritis yang mengkaji konsep dan teori terkait wakaf dari era klasik hingga era kontemporer. Kajian ini menemukan bahwa wakaf memiliki urgensi dan signifikansi yang besar terhadap pembangunan. Wakaf juga menjadi instrumen keuangan sosial yang berimplikasi langsung terhadap perekonomian. Implikasi tersebut baik dalam jangka pendek maupun jangka panjang. Dari temuan tersebut, direkomendasikan kepada para nazhir wakaf untuk mengembangkan pengelolaan wakaf yang lebih optimal dalam memberikan maslahat dan manfaat bagi masyarakat luas. Selain itu, direkomendasikan pula kepada Pemerintah untuk turut berperan dalam mendorong pengembangan pengelolaan wakaf nasional, agar perkembangan wakaf semakin tumbuh, dan turut berkontribusi aktif dalam perekonomian nasional. Sehingga hal tersebut dapat merealisasikan kesejahteraan masyarakat secara adil dan berkelanjutan.
\end{abstract}

Kata kunci: Wakaf; Keuangan Sosial; Perekonomian; Negara 


\section{PENDAHULUAN}

Persoalan rumit yang dihadapi oleh negara adalah kemiskinan dan ketimpangan pendapatan (Rohim, 2018). Persoalan tersebut massif dan struktural serta terjadi secara meluas pada setiap lapisan masyarakat. Pemegang kekuasaan sekaligus kekuatan ekonomi paling besar adalah negara. Karena itu sudah sewajarnya jika Negara mengemban tugas mulia dalam hal mengatasi kemiskinan. Sekalipun begitu, tidak menutup kemungkinan setiap lapisan masyarakat mempunyai peranan yang signifikan dalam mengentaskan kemiskinan. Bahkan peran agama juga sangat dimungkinkan dalam hal ini (S. Arif, 2010).

Ajaran Islam memiliki instrumen zakat dan wakaf. Penerapan kedua instrumen tersebut berpotensi besar mengurangi angka kemiskinan yang bersifat "struktural" secara signifikan (Riza Prima Hendra, 2003).

Upaya menuntaskan kemiskinan dapat dilakukan diantaranya dengan menggunakan instrumen wakaf. Dimana perkembangan wakaf saat ini mengalami pertumbuhan yang sangat pesat di indonesia. Berdasarkan data dari Kementerian Agama, jumlah tanah wakaf di Indonesia sebanyak 430,766 lokasi dengan luas mencapai 1,615,791,832.27 meter persegi (Direktorat Pemberdayaan Wakaf, 2008). Dari data berikut dapat dilihat jika seluruh lahan dapat dimanfaatkan secara merata dan juga effisien diperkirakan akan menghasilkan suatu pengaruh yang besar pada perekonomian di indonesia khususnya dalam upaya pemberdayaan masyarakat dan mengentaskan kemiskinan.

Sesungguhnya investasi dana wakaf adalah untuk orang itu sendiri memperoleh pahala dari Allah SWT dan dapat berkontribusi dalam pembangunan ekonomi umat. Yang lebih penting lagi investasi dana wakaf tersebut ialah untuk mengoptimalkan fungsi harta wakaf yang berguna sebagai prasarana untuk meningkatkan kualitas hidup dan kehidupan yang layak pada sumber daya insani (Hidayat, 2016).

Dalam pelaksanaannya, wakaf digunakan sebagai instrumen penerimaan negara, yang kemudian disalurkan sebagai pengeluaran negara. Sehingga wakaf dapat menjadi salah satu instrumen bagi negara dalam melakukan belanja. Adapun saat ini, wakaf dapat dioptimalkan sebagai penyangga anggaran negara, mengingat wakaf belum menjadi instrumen utama dalam membiayai belanja negara.

Kebijakan pengeluaran belanja negara atau biasanya dikenal dengan kebijakan fiskal merupakan kebijakan alternatif yang digunakan pemerintah untuk mencapai tujuan pembangunan. Kebijakan fiskal adalah kebijakan yang dilakukan pemerintah dalam mempengaruhi perekonomian dalam mengelola penerimaan dan pengaluaran negara yang berhubungan dengan perpajakan. Kebijakan pengeluaran negara atau kebijakan fiskal harus menjamin pemenuhan kebutuhan 
pokok yang ditujukan kepada seluruh warga negara tanpa memandang bagaimana warga negara tersebut.

Anggaran pemerintah untuk pengeluaran belanja negara memiliki dampak substansial terhadap perekonomian. Sebelum adanya UU No.17 Tahun 2003 tentang keuangan negara, Pengeluaran negara dibedakan atas pengeluaran rutin dan pengeluaran pembangunan (dual-budgeting). Pengeluaran rutin pemerintah di Indonesia yaitu seperti belanja pegawai, belanja barang, belanja rutin daerah, bunga dan cicilan, subsidi dan pengeluaran yang bersifat non departemen. Pengeluaran pembangunan yang ada di Indonesia merupakan pengeluaran negara untuk membiayai proyek pembangunan yang bersifat fisik dan non fsik dalam periode tertentu. Kebijakan pengeluaran negara juga memiliki pengaruh karena pengeluaran negara yaitu produksi, distribusi, konsumsi, dan keseimbangan perekonomian.

Kebijakan pengeluaran negara tidak pernah lepas dari pengeluaran non zakat seperti wakaf. Instrumen ini dapat difungsikan sebagai fasilitas untuk melancarkan program pengeluaran negara. Kebijakan belanja negara dalam Islam memiliki tujuan utama untuk mengembangkan masyarakat yang berdasarkan kepada distribusi kekayaan berimbang dengan memperhatikan nilai material dan nilai spiritual pada kedudukan yang sama. Kegiatan-kegiatan yang menambah pengeluaran harus digunakan untuk mencapai tujuan ekonomi dan sosial tertentu dalam kerangka umum hukum islam seperti ditetapkan dalam Al-Qur'an dan Hadist. Pada sisi lain jika defisit anggaran terjadi dalam memenuhi kepentingan publik, maka dapat dikeluarkan pajak baru atau melakukan pinjaman kepada publik (Al-Mawardi, 1996). Kebijakan ini pernah pula diterapkan Nabi Muhammad SAW untuk membiayai kepentingan perang dan kebutuhan publik lainnya.

Pada saat ini, di Indonesia instrumen utama yang sering digunakan dan berkembang hanya pada instrumen zakat saja. Intrumen-instrumen lainnya seperti wakaf masih jarang digunakan dan dikembangkan karena selama ini hanya dijadikan instrumen tambahan atau alternatif. Oleh karenanya, kajian ini akan mendalami signifikansi peran wakaf dalam keuangan negara, yang memiliki dampak yang besar dalam pelaksanaannya.

\section{TINJAUAN PUSTAKA}

\section{A. Konsep Belanja Negara}

Kebijakan pengeluaran adalah unsur kebijakan yang mengatur dimana pemerintah membelanjakan pendapatan yang telah dikumpulkan untuk di distribusikan pendapatan tersebut kepada masyarakat dan kebijakan ini pula diharapkan dapat menggerakan perekonomian yang ada dimasyarakat. Pendapatan yang dihimpun pemerintah harus dapat menjamin pemenuhan 
kebutahan pokok, meningkatkan taraf hidup masyarakat dan dapat meningkatkan ketakwaan seluruh warga negara tanpa pandang bulu. Hanya saja intervensi negara melalui kebijakan fiskal diperlukan berupa jaminan pemenuhan akan pangan, sandang dan papan khusus ditunjukan kepada warga negara miskin (Huda, 2012).

Belanja negara menurut Pasal 1 Angka 7 UU Nomor 35 Tahun 2000 Tentang APBN Tahun 2001 adalah semua pengeluaran negara untuk membiayai belanja pemerintah pusat dan dana perimbangan. Dalam konsep ekonomi Islam, belanja negara harus sesuai dengan syari'iyyah dan penentuan skala prioritas (Huda, 2012). Para ulama terdahulu telah memberikan kaidah umum yang disyariatkan dalam al-quran dan hadits dalam memandu kebijakan belanja pemerintah. Kaidah-kaidah tersebut sebagai berikut:

1. Timbangan kebijakan pengeluaran dan belanja pemerintahan harus senantiasa mengikuti kaidah maslahah.

2. Menghindari masyaqqah (al-masyaqqah), menurut arti bahasa adalah at$t a^{\prime} a b$, yaitu kelelahan, kepayahan, kesulitan dan kesukaran.

3. Mudarat individu dapat dijadikan alasan demi menghindari mudarat skala besar.

4. Pengorbanan individu atau kerugian individu dapat dikorbankan demi menghindari kerugian dan pengorbanan dalam skala umum.

5. Kaidah "al-giurmu bil gunmi", yaitu kaidah yang menyatakan bahwa yang mendapatkan manfaat harus siap menanggung beban.

6. Kaidah "maa la yatimmu al-wa'jibu illa' bihi fahuwa wa'jib", yaitu kaidah yang menyatakan bahwa sesuatu hal yang wajib ditegakkan, dan tanpa ditunjang oleh faktor penunjang lainnya tidak dapat dibangun, maka menegakkan faktor penunjang tersebut menjadi wajib hukumnya.

Adapun kaidah syariah yang berkaitan dengan belanja kebutuhan operasional pemerintah yang rutin mengacu pada kaidah-kaidah yang telah disebutkan di atas, secara lebih perinci pembelanjaan negara harus didasarkan pada hal-hal berikut ini (Huda, 2012):

1. Bahwa kebijakan belanja rutin harus sesuai dengan asas maslahat umum, tidak boleh dikaitkan dengan kemaslahatan seseorang atau kelompok masyarakat tertentu, apalagi kemaslahatan pemerintah.

2. Kaidah atau prinsip efisiensi dalam belanja rutin, yaitu mendapatkan sebanyak mungkin manfaat dalam biaya semurah-murahnya, dengan sendirinya jauh dari sifat mubadzir dan kikir di samping alokasinya pada sektor-sektor yang tidak bertentangan dengan syariah.

3. Kaidah selanjutnya adalah tidak berpihak pada kelompok kaya dalam pembelanjaannya, walaupun dibolehkan berpihak pada kelompok miskin. Kaidah tersebut cukup berlandaskan pada nas-nas yang sahih seperti pada 
kasus "al-hima" yaitu tanah yang diblokir oleh pemerintah yang khusus diperuntukkan bagi kepentingan umum. Ketika tanah dikhususkan untuk pengembalaan ternak kaum duafa oleh Rasulullah, ternak-ternak milik para agniya atau orang kaya dilarang untuk digembalakan di sana. Umar pernah berkata: "Hati-hati jangan sampai ternak Abdurrahman bin Auf mendekati lahan pengembalaan untuk kaum dhuafa"

4. Kaidah atau prinsip komitmen dengan aturan syariah, maka alokasi belanja negara hanya hanya boleh pada hal-hal yang mubah dan menjauhi yang haram.

5. Kaidah atau prinsip komitmen dengan skala prioritas syariah, di mulai dari yang wajib, sunah, dan mubah.

Efisiensi dan efektifitas merupakan landasan pokok dalam kebijakan belanja negara. Sebagai suatu panduan pokok bagi pengeluaran publik, teori pengeluaran Islam memakai kaidah-kaidah yang diambil dari Al-Qawaid AlFiqhiyyah guna menghindari potensi-potensi inefisiensi pengeluaran, dan juga norma-norma konsumsi Islam, serta dijadikankaidah rasionalitas bagi pengeluaran Negara. Menurut Asy-Syatibi sebagaimana dikutip (Chapra, 2000) Enam kaidah tersebut adalah:

1. Kriteria pokok bagi semua alokasi pengeluaran harus digunakan untuk kemashalatan rakyat.

2. Penghapusan kesulitan dan kerugian harus di dahulukan dari pada penyediaan kenyamanan.

3. Kemaslahatan mayoritas yang lebih besar harus di dahulukan dari pada kemaslahatan minoritas yang lebih sedikit.

4. Suatu pengorbanan atau kerugian privat dapat ditimpakan untuk menyelamatkan pengorbanan atau kerugian publik, dan suatu pengorbanan atau kerugianyang lebih besar dapat dihindarkan dengan memaksakan pengorbanan atau kerugian yang lebih kecil.

5. Siapapun yang menerima manfaat harus bersedia menanggung biaya.

6. Sesuatu hal yang wajib ditegakan dan tanpa ditunjang oleh faktor penunjang lainnya tidak dapat dibangun, maka menegakan faktor penunjang tersebut menjadi wajib hukumnya.

Selain itu, belanja pemerintah memiliki tujuan yang sangat spesifik. Beberapa tujuan pembelanjaan pemerintah dalam Islam, sebagai berikut (Huda, 2012):

1. Pengeluaran demi memenuhi kebutuhan hajat masyarakat.

2. Pengeluaran sebagai alat retribusi kekayaan.

3. Pengeluaran yang mengarah pada semakin bertambahnya permintaan efektif.

4. Penegeluaran yang berkaitan dengan investasi dan produksi. 
5. Pengeluaran yang bertujuan menekan tingkat inflasi dengan kebijakan intervensi pasar.

Dalam implementasinya, belanja pemerintah harus pula mengacu kepada kebijakan belanja umum pemerintah dalam sistem ekonomi syariah. Beberapa kebijakan tersebut dapat dibagi menjadi tiga bagian, sebagai berikut (Huda, 2012):

1. Belanja kebutuhan operasional pemerintah yang rutin.

2. Belanja umum yang dapat dilakukan pemerintah apabila sumber dananya tersedia.

3. Belanja umum yang berkaitan dengan proyek yang disepakati oleh masyarakat berikut sistem pendanaannya.

\section{B. Potensi Wakaf di Indonesia}

Wakaf merupakan salah satu instrumen keuangan sosial dalam ekonomi Islam. Sejak zaman Rasulullah SAW wakaf memiliki peran sentral dalam kehidupan ekonomi umat. Misalnya, wakaf sahabat Rasulullah SAW, Utsman bin Affan. Sebagai seorang yang dermawan, Utsman bin Affan merasa terpanggil untuk membantu kaum muslimin Madinah yang kesulitan air minum dengan menawarkan pemiliknya sistem sewa. Mekanismenya adalah pemilik dan penyewa akan menggunakan sumur terebut bergantian setiap harinya. Skema ini berhasil dijalankan. Umat islam secara tertib teratur menggunakan sumur tersebut. Karena merasa rugi, pemiliknya menjual sumur tersebut 20.000 dirham. Sampai sekarang, wakaf sumur tersebut terus berkembang dan manfaatnya banyak dirasakan oleh manusia. (Syakir, 2016)

Dari kasus di atas, dapat disimpulkan bahwa wakaf memiliki asas manfaat dari wakaf yang sangat besar baik bagi umat Islam itu sendiri maupun bagi masyarakat umum kebanyakan. Sehingga pada hakikatnya, potensi wakaf terbilang sangat besar, khususnya di Indonesia. Dilihat dari demografinya Indonesia dengan jumlah mayoritas muslim terbanyak di dunia atau lebih spesifik berdasarkan data Global Religious Futures (2018) sebanyak 204 juta orang lebih adalah orang beragama Islam yang artinya jumlah tersebut mewakili lebih dari 87 persen penduduk Indonesia. Dari jumlah orang yang beragam Islam inilah potensi perkembangan wakaf dapat dilihat.

Di Indonesia sendiri regulasi yang mengatur tentang tata tertib perwakafan tercantum semenjak disahkannya Undang-Undang Nomor 41 Tahun 2004 tentang Wakaf, Indonesia memilki payung hukum yang konkret tentang penyelenggaraan wakaf di Indonesia. Selain undang-undang itu, regulasi yang mendukung penyelenggaraan wakaf di Indonesia adalah sebagai berikut (Fathoni, 2019).

1. Peraturan Pemerintah Nomor 42 Tahun 2006 tentang Pelaksanaan UndangUndang Nomor 41 Tahun 2004 tentang Wakaf. 
2. Peraturan Meteri Agama Nomor 73 Tahun 2013 tentang Tata Cara Perwakafan Benda Tidak Bergerak dan Benda Bergerak Selain Uang

3. Peraturan Menteri Agama Nomor 4 Tahun 2009 tentang Administrasi Pendaftaran Wakaf Uang

4. Peraturan Badan Wakaf Indonesia Nomor 1 Tahun 2008 tentang Prosedur Penyusun Rekomendasi terhadap Permohonan Penukaran/Perubahan Status Harta Benda Wakaf

5. Peraturan Badan Wakaf Indonesia Nomor 3 Tahun 2008 tentang Tata Cara Pendaftaran dan Pergantian Nazhir Harta Benda Wakaf Tidak Bergerak Berupa Tanah

6. Peraturan Badan Wakaf Indonesia Nomor 1 Tahun 2009 tentang Pedoman Pengelolaan dan Pengembangan Harta Benda Wakaf Berupa Uang.

Peraturan tersebut juga berperan sebagai cikal bakal lahirnya lembaga wakaf yang dicetuskan oleh pemerintah yakni Badan Wakaf Indonesia (BWI). Kehadiran BWI ditunjukan untuk membina nazhir dalam mengelola aset wakaf agar lebih baik dan produktif sehinga bisa memberikan manfaat yang lebih besar kepada masyarakat, baik berupa pemberdayaan ekonomi, pelayanan sosial, hingga pembangunan infrastruktur.

Menurut data Kementerian Agama, saat ini luas tanah Wakaf di Indonesia 51.251,35 hektar dimana 61,13 persen dari luas tanah wakaf tersebut telah bersertifikat dengan perincian sebagai berikut (Fathoni, 2019):

1. 28,41 persen dalam bentuk rumah ibadah/Musholla

2. $44,, 36$ persen dalam bentuk rumah ibadah/Masjid

3. 4,45 persen berupa makam

4. 3 persen berbentuk sarana pendidikan/Sekolah

5. 3,48 persen dalam bentuk Pesantren

6. 8,61 persen dalam bentuk Sosial lainnya

Tanah yang luas tersebut bila dikelola secara produktif tentunya akan membawa hasil yang besar yang dapat membantu ekonomi umat. Selain itu juga sekarang hadir inovasi dalam membayar wakaf, berupa cash waqf (wakaf tunai). Wakaf ini menggunakan objek wakaf berupa uang, sehingga sering juga disebut wakaf uang. Bank Indonesia mendukung pelaksanaan wakaf tunai di Indonesia dalam memberikan ruang gerak (fleksibilitas) kepada wakaf di era globalisasi seperti saat ini. Pada saat ini menurut BWI wakaf uang memiliki potensi sebesar Rp188 triliun per tahun. Melalui wakaf uang ini juga, peluang investasi yang unik dapat tercipta di berbagai bidang, seperti bidang ekonomi, pendidikan, keagamaan dan pelayanan social. Selanjutnya bank syariah akan menerbitkan Sertifikat Wakaf Tunai (SWT) sebagai bukti atas penyaluran wakaf tunai yang telah dilakukan. Kemudian uang yang ditunjukan untuk wakaf tunai dibelanjakan 
dengan berbagai tujuan yang berbeda, diantaranya untuk pemeiharaan harta wakaf dan membiayai berbagai pengeluaran investasi lainnya (Fathoni, 2019).

Melalui penerbitan SWT akan tercipta penggalangan dana dengan jumlah yang besar karena:

1. Ruang lingkup sasaran wakaf tunai bisa menjadi lebih luas daripada wakaf jenis harta lainnya

2. SWT dapat dibuat dalam berbagai pecahan. Hal ini karena SWT menyesuaikan pendapatan dari segmen muslim yang dituju. Contoh dari pecahan yang dapat diterbitkan adalah Rp. 10.000 , Rp. 25.000,Rp. 50.000, dan Rp. 100.000

Wakaf memiliki dua unsur utama, pertama unsur spiritual karena wakaf merupakan cabang ibadah yang dapat mendekatkan diri wakif kepada Allah SWT. Kedua unsur material karena wakaf difahami sebagai usaha menjadikan harta dari kepentingan konsumsi menjadi modal investasi yang dapat menghasilkan barang dan jasa untuk kepentingan masa depan.

Undang-undang No. 41 Tahun 2004 Pasal 16 membagi jenis harta benda wakaf menjadi dua, yaitu benda tidak bergerak dan benda bergerak. Uang digolongkan menjadi salah satu harta benda wakaf bergerak. Penerapan wakaf tunai pada masa sekarang, mempunyai keunggulan yang lebih besar dari wakaf tradisional, yaitu benda-benda fisik yang tidak bergerak. Secara umum, wakaf benda tidak bergerak hanya dapat dilakukan oleh orang yang memiliki harta lebih. Sedangkan wakaf tunai dapat dilakukan banyak orang, meskipun tidak kaya.

Wakaf tunai adalah wakaf berupa uang dalam bentuk rupiah yang kemudian dikelola oleh nazhir secara produktif, hasilnya dimanfaatkan untuk mauquf 'alaih. Dengan demikian, dalam wakaf tunai, uang yang diwakafkan tidak boleh diberikan langsung kepada mauquf 'alaih, tetapi harus diinvestasikan lebih dulu oleh nazhir, kemudian hasil investasinya diberikan kepada mauquf 'alaih (Aziz, 2017).

Dalam perundang-undangan Indonesia melalui Undang-Undang No 41 tahun 2004, Indonesia bisa menjadikan dana wakaf tunai sebagai sarana pengembangan ekonomi. Badan Wakaf Indonesia (BWI) merupakan sebuah lembaga independen yang membawahi nazhir wakaf nasional yang berdiri sejak tahun 2007 berdasarkan Kepres Kepres No. 75/M/2007 Tanggal 13 Juli 2007 tentang Kepengurusan Badan Wakaf Indonesia. Tercatat hingga 19 Oktober 2017, terdapat 187 lembaga nazhir wakaf tunai yang telah resmi terdaftar di BWI.

$\mathrm{Di}$ Indonesia wakaf sudah diatur secara formal oleh peraturan perundangan yang sangat progresif dalam mengakomodir tentang wakaf, maka diharapkan mampu melakukan pengembangan konsep wakaf ke arah yang jauh lebih baik dari sebelumnya. Saat ini yang diharapkan adalah tindakan nyata dan bukan sekedar berwacana. Indonesia yang memiliki jumlah umat Islam terbesar di dunia merupakan suatu aset untuk penghimpunan dan pengembangan wakaf 
tunai. Jika wakaf tunai dapat diimplementasikan dengan baik maka akan terdapat dana potensial yang dapat dipergunakan bagi kemaslahatan umat.

Pada akhirnya wakaf tunai mempunyai manfaat yang tidak dimiliki oleh wakaf benda tidak bergerak. Setidaknya terdapat empat manfaat utama dari wakaf tunai dewasa ini dalam mewujudkan masyarakat yang berkeadilan sosial yang antara lain sebagai berikut:

1. Wakaf tunai jumlahnya bisa bervariasi sehingga seseorang yang memiliki dana terbatas sudah dapat mulai memberikan dana wakafnya tanpa harus menggu menjadi tuan tanah dahulu.

2. Melalui wakaf tunai, aset-aset wakaf yang berupa tanah-tanah kosong bisa mulai dimanfaatkan dengan pembangunan gedung atau diolah untuk lahan pertanian.

3. Dana wakaf uag juga bisa membantu sebagian lembaga-lembaga pendidikan Islam yang aliran dananya terkadang kembang-kempis dan menggaji civitas akademika seadanya.

4. Pada gilirannya umat Islam dapat lebih mandiri dalam mengembangkan dunia pendidikan tanpa harus terlalu bergantung pada anggaran pendidikan dan sosial negara yang sangat terbatas (Hasan, 2010).

Wakaf tunai membuka peluang yang unik untuk menciptakan investasi guna memberikan pelayanan keagamaan, layanan pendidikan, dan layanan sosial. Wakaf tunai bisa menjadi solusi untuk memberdayakan aset wakaf nasional yang idle atau menganggur dan tidak termanfaatkan selama ini. Di Indonesia saat ini wakaf tunai dilihat dari segi infrastrukturnya telah lengkap dan tinggal pelaksaaananya saja.

Jika wakaf tunai dapat diimplementasikan dengan baik di Indonesia maka akan terdapat dana potensial yang dapat dipergunakan dalam mewujudkan kesejahteraan sosial dan membantu mengatasi masalah perekonomian di Indonesia. Wakaf tunai sangat potensial untuk menjadi sumber pendanaan abadi guna melepaskan bangsa dari jerat hutang dan ketergantungan luar.

\section{PEMBAHASAN}

\section{A. Wakaf sebagai Penerimaan Negara}

Wakaf merupakan salah satu instrumen penerimaan negara khususnya pada zaman Rasulullah SAW, dimana harta wakaf tersebut tidak akan berkurang nilainya dan ditujukan untuk memberikan manfaat kepada umat seperti untuk fasilitas untuk kesejahteraan masyarakat maupun sarana-prasarana ibadah agar kemaslahatan terpenuhi. Jadi, wakaf bukan hanya berbentuk pemberian al-quran kepada masjid saja yang seperti pada umumnya telah diketahui. Khususnya pada zaman Rasulullah SAW, wakaf memiliki kontribusi yang cukup tinggi. Wakaf memang tidak diperuntukkan mencari keuntungan dari perekonomian, justru 
membutuhkan modal dan dana untuk keberlangsungannya. Bentuk-bentuk dari wakaf tersebut antara lain masjid, pondok pesantren, madrasah, kuburan, rumah sakit, panti asuhan, dan lain-lain. (Khusaeri, 2015)

Dalam ajaran Islam, wakaf merupakan ibadah sosial yang bersamaan dengan investasi sosial melalui pengeluaran harta yang penting. Wakaf memiliki nilai yang bermanfaat dengan skala panjang atau biasa disebut dengan fixed asset yang mewujudkan ibadah harta. Pada masa lampau, wakaf menjadi elemen pendukung penyediaan fasilitas sosial maupun fasilitas umum untuk masyarakat (Juhro et al., 2019). Dari sini dapat dipahami bahwa wakaf memiliki dampak yang nyata untuk kehidupan masyarakat dimana kesejahteraan tersebut menjadi harapan sehingga menjadi indikator pencapaian taraf kehidupan yang layak dan bersahaja. Wakaf ketika awal Islam dalam istilahnya dikenal juga sebagai shadaqah. Dalam dunia Islam sebenarnya yang pertama kali melakukan shadaqah/wakaf ini masih belum diketahui pasti. Namun, untuk para kaum Muhajirin meyakini bahwa yang pertama melakukanya adalah Umar bin Khattab. Sedangkan kaum Anshar mempercayai bahwa Rasulullah SAW adalah orang pertama yang melakukan wakaf (Muhtar, 2015).

Wakaf sendiri berasal dari bahasa Arab yakni "waqafa" yang artinya berhenti dan menahan. Jika dalam istilah, menurut Undang-undang Wakaf No. 41 tahun 2004 wakaf merupakan perbuatan hukum seseorang atau kelompok orang atau badan hukum yang memisahkan sebagian dari benda miliknya dan melembagakannya untuk selama-lamanya guna kebentingan ibadat atau keperluan umum lainnya sesuai dengan ajaran agama Islam.

Pengertian wakaf di atas juga memunculkan beberapa ciri khas wakaf, yaitu (Rahman, 2009):

1. penahanan (pencegahan) dari menjadi milik dan obyek yang dimilikkan. Penahanan berarti ada yang menahan yaitu wakif dan tujuannya yaitu mauquf 'alaihi (penerima wakaf);

2. harta, menjelaskan bahwa yang diwakafkan adalah harta;

3. kemungkinan pemanfaatan tanpa lenyap bendanya, menjelaskan syarat harta yang diwakafkan;

4. dengan cara tidak melakukan tindakan pada bendanya, menjelaskan bahwa harta wakaf tidak dijual, dihibahkan dan diwariskan;

5. disalurkan kepada yang mubah dan ada, menjelaskan bahwa hasil wakaf itu disalurkan kepada yang tidak dilarang oleh Islam. Sedangkan, menyalurkannya kepada yang haram adalah haram.

Dengan demikian, kewajiban-kewajiban dalam syariah menyangkut perlindungan maqashid syariah yang ada pada gilirannya bertujuan untuk melindungi kemaslahatan manusia. Asy-Syatibi menjelaskan bahwa syariah berurusan dengan perlindungan mashalih, baik dengan cara yang positif seperti 
demi menjaga eksistensi mashalih, syariah mengambil berbagai tindakan untuk menunjang landasan-landasan mashalih, maupun dengan cara preventif, seperti syariah mengambil berbagai tindakan untuk melenyapkan unsur apapun yang secara aktual dan potensial merusak mashalih. Menurut asy-Syatibi, kemaslahatan dapat terealisasi apabila lima unsur pokok kehidupan manusia dapat diwujudkan dan dipelihara, yaitu agama, jiwa, akal, keturunan dan harta. Dengan kata lain, eksternalitas negatif atas pengelolaan barang publik tidak akan terjadi apabila tujuan pengelolaannya sejalan dengan maqashid syariah. (Sancoyowati, 2018)

Dalam rangka pembinaan wakaf agar tetap berfungsi sebaimana mestinya, hal-hal yang harus dilakukan oleh pihak-pihak yang memiliki otoritass dan kewenangan, hususnya pemerintah, lembaga kenadziran, lembaga swadaya masyarakat (LSM) yang peduli terhadap pemberdayaan wakaf dan pihak terkait lainnya adalah (Khusaeri, 2015):

1. Mengimplementasikan undang-undang No. 41 Tahun 2004 tentang wakaf. Kehadiran ini sangat penting bagi perlindungan tanah-tanah wakaf dan harta wakaf lainnya yang selama ini terdata oleh Kementerian Agama dan sebagai regulasi pemberdayaan potensi wakaf secara lebih optimal, baik berupa benda bergerak maupun tidak bergerak. Dengan Undang-Undang khusus wakaf ini diharapkan perlindungan, pemanfaatan dan pemberdayaan harta wakaf secar maksimal tidak mengalami hambatan yang serius.

2. Membenahi sumberdaya manusia (SDM) yang duduk dalam lembagalembaga kenadziran. Karena lembaga kenadziran memiliki peran sentral dalam pengelolaan harta wakaf secara umum. Untuk itu eksistensi dan kualitas SDM tersebut harus betulbetul diperhatikan. Secara umum, kemampuan SDM Nadzir dalam mengelola wakaf dapat terarah dan terbina secara optimal. Kemudian yang paling penting selain professional adalah dapat dipercaya (amanah). Tentu saja pemaknaan amanah disini tidak berhenti pada aspek moral saja, namun nilai-nilai profesionalisme juga akan menentukan apakah lembaga tersebut pada akhirnya bisa dipercaya atau tidak.

3. Mengamankan seluruh kekayaan wakaf, baik pada tingkat pusat maupun daerah. Upaya pengamanan ini agar harta berstatus wakaf tidak diganggu gugat oleh pihak-pihak yang tidak bertaggung jawab. Oleh karena itu, jika harta wakaf berupa tanah, maka yang harus dilakukan adalah:

a. Segera memberikan sertifikat tanah wakaf yang ada di seluruh pelosok tanah air. Harus diakui, banyak tanah-tanah wakaf yang jatuh ke tangan atau pihak-pihak yang tidak berhak. Dan ini harus dihentikan dengan memberikan sertifikat terhadap tanah-tanah yang berstatus wakaf.

b. Melakukan dukungan advokasi terhadap tanah-tanah yang masih sengketa. Tanah-tanah yang diserahkan kepada nazhir wakaf sebelum PP 
No. 28 Tahun 1977 banyak yang tidak mempunyai bukti wakaf, sehingga tanah wakaf yang seharusnya menjadi milik Allah dan hak masyarakat banyak berpindah ke tangan orang-orang yang tidak bertanggung jawab. Keberpindahan kepemilikan tanah wakaf bisa saja dilakukan oleh oknum nadzir yang nakal, keluarga wakif yang merasa mempunyai hak atas tanah maupun orang lain yang mempunyai kepentingan dengan tanah-tanah tersebut.

c. Pemanfaatan dan pemberdayaan tanah wakaf secara produktif. Di samping pengamanan di bidang hukum, pengamanan di bidang peruntukan dan pengembangannya juga harus dilakukan. Sehingga antara perlindungan hukum dengan aspek hakikat tanah wakaf yang memiliki tujuan sosial menemukan fungsinya.

4. Mengadakan pengawasan yang ketat terhadap pelaksanaan pengolaan tanah wakaf. Dukungan ini diperlukan agar tanah-tanah wakaf, khususnya tanah wakaf produktif strategis yang ada menjadi aman karena dirasakan adanya upaya pihak-pihak tertentu, termasuk oknum nadzir yang ingin menukar dengan tanah-tanah yang tidak strategis.

5. Menstimulasi atau mendorong secara lebih luas kepada masyarakat agar lebih peduli terhadap pentingnya harta wakaf di tengah kehidupan sosial kemasyarakatan.

Kelima langkah tersebut merupakan konsekuensi logis yang harus dilakukan oleh pemerintah, lembaga nadzir, lembaga swadaya masyarakat dan pihak terkait lainnya sebagai upaya pembinaan yang bersifat menyeluruh dan konkrit agar wakaf tetap memiliki peran yang signifikan di tengah kebutuhan perbaikan dalam kehidupan sosial masyarakat banyak.

Potensi wakaf yang sangat besar harus dikelola dengan baik agar menghasilkan manfaat yang luas dan resiko berkurangnya jumlah harta wakaf dapat diminimalisir sehingga ideal untuk dijadikan penerimaan negara. Macammacam wakaf ini beraneka ragam, antara lain seperti wakaf produktif yang dapat mendatangkan hasil dan menguntungkan, wakaf uang yang berbentuk uang tunai untuk surat-surat berharga, wakaf tanah yang merupakan tanah hak milik seseorang yang telah diwakafkan, dan sebagainya.

Wakaf juga dapat dijadikan sumber pendapatan negara non pajak yang secara potensi lebih besar dibandingkan potensi dari pajak itu sendiri. Sebagai instrumen keuangan Islam maka pengelolaan wakaf harus sesuai dengan tujuan yang sudah diatur oleh Islam melalui al-quran dan hadits yang lebih dikenal dengan maqashid syariah. Pengelolaan wakaf secara baik akan dapatmendorong peran wakaf sebagai instrumenpembangunan negara. (Sancoyowati, 2018) 


\section{B. Kebijakan Pengeluaran Negara Masa Awal Islam \\ Masa Rasulullah SAW}

Sebidang tanah dari Mukhairik, seorang Yahudi yang terbunuh pada saat perang Uhud. Sebelum kematiannya telah berwasiat untuk memberikan tanah tersebut kepada Nabi, kemudian Nabi mewakafkan tanah tersebut. Pada masa Umar bin Abdul Aziz, kurma yang dihasilkan dari tanah Mukhairik sangat terkenal cita dan rasanya. Imam ibn Syabbah menyebutkan, bahwa ketujuh kebun Mukhairik itu bernama; al-Dalal, Barqah, al-A'waf, al-Shafiyah, al-Matsyab, Husna, dan Masyrabat Umm Ibrahim (Al-Hujaili, 1999).

Wakaf berikutnya berasal dari harta rampasan perang Bani Nadhir yang dimanfaatkan Rasulullah SAW untuk keluarga dan keturunannya. Namun demikian, Rasulullah hanya mengambil kecukupan manfaat wakaf untuk keluarganya selama setahun, dan sisanya dibelikan peralatan perang untuk jihad di jalan Allah. Ketentuan pembagian harta rampasan tersebut bukan dari perintah Rasulullah, melainkan firman Allah SWT dalam surat al-Hasyr ayat 6 (Al-Sayyid, 1968).

Lainnya, seperti harta rampasan perang dari Khaibar dan Fadak diberikan Rasulullah untuk keluarga dan sahabat-sahabatnya. Namun, (Al-Hujaili, 1999) mengatakan bahwa harta dari Fadak diwakafkan bagi keperluan ibnu sabīl, disisi lain Khaibar dibagi menjadi tiga, dua bagian untuk kaum muslimin, satu bagian untuk keluarga Rasulullah, sedangkan sisanya diberikan Rasulullah kepada kaum fakir miskin dari kaum Muhajirin. Harta-harta lainnya, seperti rumah, peralatan perang, perlengkapan pakaian, hewan tunggangan dan ternak, juga diwakafkan setelah wafatnya Rasulullah. Tetapi, sebagian besar sudah sulit dicari keberadaannya saat ini, kecuali beberapa yang masih tersimpan dalam peninggalan sejarah.

Kemudian juga ada beberapa bangunan masjid yang dibangun di beberapa tempat dakwah Rasulullah SAW. Masjid-masjid tersebut, antara lain masjid Nabawi, Kuba, al-ljabah, Bani Anif, Bani Haram, Bani Dinar, Bani Dhafar, Jum'ah, dan masih ada masjid-masjid lainnya (Al-Ghani, 1999). Pada saat Rasulullah hidup, pengelolaan wakaf dipercayakan kepada Abu Rafi' yang memiliki nama asli Ibrahim. Setelah wafat, pengelolaan wakaf diserahkan kepada Ali bin Abi Thalib, dilanjutkan Hasan bin Ali, kemudian Husain bin Ali, diserahkan kepada Ali bin Husain, seterusnya Hasan bin Hasan, Zaid bin Hasan, dan Abdullah bin Hasan, sampai kepada masa Abbasiyah (Al-Asqalāni, 1960).

Secara garis besar pengeluaran negara pada zaman Rasulullah sebagai berikut (Huda, 2012):

1. Pengeluaran primer yang diterapkan pada zaman Rasulullah meliputi biaya pertahanan, seperti persenjataan, unta, kuda, dan persediaan, penyaluran zakat dan usyr sesuai ketentuan al-quran bagi yang berhak menerimanya, 
pembayaraan gaji untuk wali, qadhi, guru, imam, muazin, pejabat negara lainnya, pembayaraan upah para sukarelawan, pembayaran utang negara, dan bantuan untuk musafir (dari daerah Fadak).

2. Pengeluaran sekunder yang diterapkan pada zaman Rasulullah SAW meliputi bantuan untuk orang-orang di Madinah yang sedang belajar agama, hiburan untuk para delegasi keagamaan, hiburan untuk para utusan suku dan negara serta biaya perjalanan merek, hadiah untuk pemerintahan negara lain, pembayaran denda bagi mereka yang terbunuh secara tidak sengaja oleh pasukan muslim, pembayaran utang orang yang meninggal dalam keadaan miskin, pembayaran tunjangan untuk orang miskin, tunjangan untuk saudarasaudara Rasulullah SAW, pengeluaran rumah tangga Rasulullah SAW, dan persediaan darurat.

Dari kebijakan yang dilakukan Rasulullah SAW, dapat disimpulkan bahwa kebijakan Rasulullah dalam menggunakan harta negara lebih diprioritaskan kepada masyarakat dan persediaan dana untuk perang, tujuannya tidak lain demi kemaslahatan umat.

\section{Masa Sahabat Rasulullah SAW}

1. Masa Khalifah Abu Bakar As-Shiddiq

Kebutuhan keluarga Abu Bakar diambil menggunakan harta baitul mal. Abu Bakar diperbolehkan mengambil 2,5 atau 3/4 dirham setiap harinya dari baitul mal dengan tambahan makanan berupa daging domba dan pakaian biasa (Karim, 2008). Namun saat mendekati akhir hidupnya, Abu Bakar memiliki kesulitan dalam mengumpulkan pendapatan negara sehingga ia menanyakan berapa banyak upah atau gaji yang diterimanya. Ketika diberitahukan bahwa jumlah tunjangannya sebesar 8000 dirham, beliau langsung memerintahkan untuk menjual sebagian besar tanah yang dimilikinya dan seluruh hasil penjualannya diberikan kepada negara (Karim, 2008).

Dalam usahanya meningkatkan kesejahteraan umat Islam, Khalifah Abu Bakar As-Shiddiq melaksanakan beberapa kebijakan ekonomi seperti yang telah dipraktekkan Rasulullah SAW. Dalam mendistribusikan harta baitul mal, Abu Bakar menerapkan prinsip kesama-rataan, yaitu memberikan jumlah yang sama dalam jumlah yang diterima oleh semua sahabat Rasulullah SAW dan tidak membedabedakan antara sahabat yang terlebih dahulu memeluk Islam dengan sahabat yang kemudian, antara hamba dengan orang merdeka, dan antara pria dan wanita (Karim, 2008).

2. Masa Khalifah Umar bin Al-Khattab

Pada masa pemerintahan Umar bin Khattab, beliau mengambil keputusan untuk tidak menghabiskan harta baitul mal sekaligus, tetapi dikeluarkan secara bertahap sesuai dengan kebutuhan yang ada, bahkan di antaranya disediakan 
dana cadangan (Karim, 2008). Secara garis besar, pengeluaran negara pada masa khalifah Umar dikeluarkan untuk kebutuhan prioritas contohnya pengeluaran dana pensiun bagi mereka yang bergabung dalam kemiliteran, baik muslim maupun non-muslim. Dana tersebut juga termasuk pensiunan bagi pegawai sipil (Majid, 2003).

Pengeluaran non-zakat menurut sumber pendapatannya adalah sebagai berikut (Huda, 2012):

a. Usyr (pajak tanah)

Dana disimpan di baitul maal dan akan dibagikan kepada delapan asnaf.

b. Khums dan sedekah

Di distribusikan kepada kaum miskin tanpa diskriminasi apakah dia muslim atau non-muslim.

c. Kharaj

Dana disimpan untuk cadangan darurat seperti membiayai angkatan perang dan kebutuhan umat.

d. Fai, jizyah, usyr (pajak perdagangan) dan sewa tanah

Digunakan untuk membayar dana pensiun, dana bantuan, serta menutupi biaya administrasi, dan lain sebagainya.

Selain itu dalam Hadis yang diriwayatkan oleh Imam Bukhari, tentang tanah di Khaibar yang bernama Samagh telah diwakafkan oleh Umar bin Khattab ra (Al-Asqalāni, 1960), serta rumah yang diwakafkan kepada anaknya di Madinah (Al-Hujaili, 1999). Hingga saat ini wakaf Khaibar dimanfaatkan untuk kebun kurma.

3. Masa Khalifah Utsman bin Affan

Khalifah Usman adalah seorang dari beberapa orang terkaya di antara beberapa sahabat Nabi. Beliau tidak mengambil upah dari baitul mal, sebaliknya Utsman malah menyimpan uangnya di bendahara negara. Hal ini menimbulkan kesalahpahaman antara khalifah dan Abdullah bin Arqam, salah satu sahabat Nabi terkemuka, yang berwenang melaksanakan kegiatan baitul mal pusat. Pada perkembangan berikutnya keadaan ini bertambah rumit bersamaan dengan munculnya pertanyaan lain yang menimbulkan kontroversi mengenai ketidakhatihatian pengeluaran uang baitul mal (Huda, 2012).

Ada beberapa kebijakan yang dilakukan Khalifah menjadi kontroversi yang menimbulkan perdebatan di kalangan umat Islam pada saat itu, seperti yang dilakukan oleh Khalifah Usman, yaitu:

a. Kebijakan untuk memberikan kepada kerabatnya harta dari baitul mal.

b. Kebijakan menggunakan dana zakat untuk pembiayaan perang atau pembiayaan lainnya.

c. Kebijakan untuk memberikan tambahan gaji para pejabat negara, beberapa di antaranya memiliki hubungan kerabat dengannya. 
Utsman bin Affan juga mewakafkan sumur Raumah yang diriwayatkan dalam Hadis Nasai, Tirmidzi, dan Bukhāri (Ghuddah, 1986); (Al-Bāqi, 1978); (AlAsqalāni, 1960). Manfaat dari wakaf sumur ini juga masih terjaga dengan baik hingga saat ini.

4. Masa Khalifah Ali bin Abi Thalib

Dalam alokasi dana untuk pengeluaran negara, yang dilakukan khalifah Ali hampir mirip dengan yang dilakukan khalifah Umar. Pengeluaran untuk angkatan laut yang ditambah jumlahnya pada masa Usman, pada masa beliau dihapuskan, karena daerah sepanjang garis pantai seperti Syria, Palestina, dan Mesir berada di bawah kekuasaan Muawiyah, sementara Muawiyah memberontak kepada beliau dengan memproklamirkan diri sebagai penguasa independen di Syria. Adapun fungsi baitul maal masih sama seperti sebelumnya. Pada masa ini tidak ada perubahan yang berarti (Huda, 2012).

Ali bin Abi Thalib juga mewakafkan hartanya di Yanbu' dan Khaibar, Mu'az bin Jabal, Asma binti Abi Bakar, serta istri-istri Rasulullah, seperti Ummu Salamah, Shafiyah binti Hayi, dan Ummu Habibah juga ikut mewakafkan rumah-rumahnya di Madinah (Al-Hujaili, 1999).

5. Sahabat Rasulullah lainnya

Sahabat-sahabat Rasulullah SAW lainnya (Al-Hujaili, 1999) seperti Sa'ad bin Abi Waqash, Abu Arwa al-Dausi, Jabir bin Abdullah, Sa'ad bin 'Ubadah, 'Uqbah bin 'Amir, Abdullah bin Zubair, Hakim bin Hazam, 'Amru bin 'dan Ash, Sa'id bin Zaid juga ikut berwakaf.

Wakaf yang diberikan oleh para sahabat secara keseluruhan dapat dikelompokkan berdasarkan bentuk dan jumlahnya secara berurut, dimulai dari wakaf rumah, tanah, peralatan perang, dan yang terakhir adalah sumber air. (AlHujaili, 1999) juga menceritakan bahwa hasil wakaf yang dikelola oleh Hafsah, istri Rasulullah yang ditunjuk sebagai nazhir oleh Umar bin Khattab, diperuntukkan kepada mujahid fi Sabilillah (orang yang berperang di jalan Allah), membebaskan hamba sahaya, bekal untuk musafir, bantuan kepada orang-orang miskin dan lemah (lemah fisik), juga diberikan kepada kerabat para wakif, serta orang-orang lanjut usia, beserta penduduk yang mengemis karena tidak berkecukupan pangan. Menurut Abu Bakar al-Hamidi, wakaf sahabat-sahabat Rasulullah SAW tersebut masih terjaga hingga saat ini (Al-Khilāl, 1989).

6. Masa Daulah Umayyah dan Daulah Abbasiyah

Pertumbuhan wakaf di Mesir, Syam dan beberapa negara yang takluk dalam pasukan Islam pada masa Daulah Umayyah sangatlah besar. Pertumbuhan wakaf ini disebabkan oleh banyaknya harta rampasan perang yang diperoleh pada saat itu. Sehingga, peruntukan hasil wakaf tidak hanya terbatas kepada fakir miskin saja, namun berkembang dalam wujud pengembangan keilmuan dan perbaikan sosial secara umum. Untuk mengawasi harta wakaf, hakim 
mendapatkan tugas sebagai nazhir yang mengawasi dan mengelola wakaf secara langsung. Taubah bin Namr adalah hakim di Mesir yang pertama kali yang menjadi nazhir sekaligus Hakim, yaitu pada masa Hisyam bin Abd al Malik berkuasa (Abdussalām, n.d.). (Mahdi, n.d.) menyebutkan, bahwa pada masa Bani Umayyah inilah pertama kali rumah sakit didirikan di Damaskus dengan menggunakan dana wakaf, yaitu pada masa Walid bin Abd al-Malik.

Adapun pada masa Daulah Abbasiyah, seorang hakim tidak lagi merangkap menjadi nazhir wakaf. Pengelola wakaf disebut dengan Shadr al-Waqf yang dibantu dengan nazhir-nazhirnya. Perkembangan wakaf pada masa ini terus meningkat, namun perkembangan ini tidak terlepas dari dampak pengelolaan wakaf pada masa Daulah Umayyah yang dirasakan oleh masyarakat. Dampak nyata itulah yang memberikan motivasi kepada masyarakat untuk berlombalomba mewakafkan hartanya (Mahdi, n.d.). Pada masa Daulah Abbasiyah tercatat, berdirinya lembaga pendidikan atau sekolah al-Mustanshiriyah di Baghdad dengan menggunakan dana wakaf.

Setelah Daulah Abbasiyah melemah, timbullah berbagai daulah seperti Daulah al-Fātimiyah al-Batiniyah, Daulah al-Ayubiyah, Daulah al-Mamalik alBahriyah di Mesir dan Syam, dan Daulah al-Utsmaniyah di Turki dan berbagai negara Arab yang terus melakukan penambahan dan perbaikan dala pengelolaan wakaf.

\section{Kebijakan Pengeluaran Negara di Masa Kontemporer}

Di masa Rasulullah SAW kebijakan anggaran sangat sederhana dan tidak serumit sistem anggaran modern. Hal ini sebagian karena telah berubahnya keadaan sosio ekonomik secara fundamental, dan sebagian lagi karena negara Islam yang didirikan dan dilaksanakan oleh Rasulullah SAW. Negara yang berlandaskan demokrasi, pada umumnya membuat anggaran belanja negara secara umum. Setiap tahun, anggaran belanja negara tersebut adalah anggaran belanjanya diatur melalui peraturan anggaran belanja negara sekian tahunan. Kemudian ditetapkan sebagai peraturan setelah dibahas dengan parlemen (Huda, 2012).

Anggaran modern merupakan suatu campuran rumit antara rencana dan proyek yang harus dilaksanakan di masa depan, maupun melenyapkan kesulitan dan rintangan yang terdapat pada jalan pertumbuhan ekonomi negara. Konsep anggaran negara Islam modern adalah dengan konsep perbedaan pokok dalam hal penanganan defisit anggaran. Negara Islam modern harus melalui pengeluaran yang mutlak diperlukan dan mencari jalan dengan langkah untuk mencapainya, baik dengan rasionalisasi struktur pajak atau melalui pengambilan kredit dari sistem perbankan atau dari luar negeri. 
Pada masa kontemporer saat ini, instrumen non-zakat yang digunakan sebagai pengeluaran adalah wakaf. Wakaf saat ini sudah berkembang mengikuti perkembangan zaman, dimana jenis-jenis wakaf saat ini semakin bertambah banyak jenisnya. Wakaf terbagi menjadi beberapa macam berdasarkan peruntukannya, jenis hartanya, batasan waktunya, dan penggunaan objeknya.

1. Wakaf Berdasarkan Peruntukannya

a. Wakaf Ahli

Wakaf ahli adalah wakaf yang memiliki tujuan untuk kepentingan dan jaminan sosial kepada wakif, lingkungan keluarga, kerabat sendiri, dan orang-orang tertentu tanpa melihat apakah kaya atau miskin, sakit atau sehat, dan tua atau muda (Usman, 1999).

b. Wakaf Sosial atau Kebaikan Masyarakat (Waqf Khairi)

Wakaf sosial atau kebaikan masyarakat adalah wakaf yang memiliki tujuan untuk kepentingan agama atau masyarakat umum (kebajikan umum) (Usman, 1999).

c. Wakaf Gabungan (Waqf Musytarak)

Wakaf gabungan adalah wakaf yang memiliki tujuan untuk kepentingan umum dan keluarga secara bersamaan (Ghanim, n.d.).

2. Wakaf Berdasarkan Jenis Hartanya

a. Wakaf Benda Bergerak Uang

Wakaf uang adalah wakaf yang dilakukan oleh orang atau badan hukum dimana harta yang diwakafkan dalam bentuk uang. Menurut Badan Wakaf Indonesia wakaf uang dilaksanakan dalam beberapa bentuk, seperti wakaf tunai/cash waqf ataupun Cash Waqf Linked Sukuk (CWLS).

b. Wakaf Benda Bergerak Selain Uang

Wakaf benda bergerak adalah wakaf yang dilakukan oleh orang atau badan hukum dimana harta yang diwakafkan adalah jenis benda bergerak yang terdiri dalam beberapa bentuk seperti uang, logam mulia, surat berharga, dan harta lainnya.

c. Wakaf Benda Tidak Bergerak

Wakaf benda tidak bergerak adalah wakaf yang dilakukan oleh orang atau badan hukum dimana harta yang diwakafkan adalah jenis benda tidak bergerak yang terdiri dalam beberapa bentuk. Bentuk-bentuk wakaf benda tidak bergerak menurut Badan Wakaf Indonesia, yaitu:

1) Hak atas tanah sesuai dengan ketentuan peraturan peundangundangan yang berlaku, baik yang sudah maupun yang belum terdaftar.

2) Bangunan atau bagian bangunan yang berdiri di atas tanah.

3) Tanaman dan benda lain yang berada di atas tanah. 
4) Hak milik dari rumah susun sesuai ketentuan peraturan perundangundangan yang berlaku.

5) Benda tidak bergerak lain sesuai syariah dan peraturan perundangundangan yang berlaku.

3. Wakaf berdasarkan batas waktunya

a. Wakaf abadi (waqf muabbad)

Wakaf abadi adalah wakaf dalam bentuk barang abadi, misalnya tanah, bangunan dengan tanahnya, dan barang bergerak yang ditentukan sebagai wakaf abadi dan produktif, dimana sebagian hasilnya untuk disalurkan sesuai tujuan wakaf, sedangkan sisanya untuk biaya perawatan wakaf dan mengganti kerusakannya (Ghanim, n.d.).

b. Wakaf sementara (waqf muaqqat)

Wakaf sementara adalah wakaf yang berbentuk barang yang mudah rusak ketika dipergunakan tanpa memberi syarat untuk mengganti bagian yang rusak. Wakaf sementara juga bisa dikarenakan oleh keinginan wakif yang memberi batasan waktu ketika mewakafkan barangnya (Ghanim, n.d.).

4. Wakaf berdasarkan penggunaan objeknya

a. Wakaf langsung (waqf mubasyir/dzati)

Wakaf langsung adalah wakaf yang hartanya digunakan untuk mencapai tujuan yang menghasilkan pelayanan masyarakat dan bisa digunakan secara langsung seperti masjid untuk shalat, sekolah/madrasah untuk kegiatan belajar mengajar, dan rumah sakit untuk tempat berobat.

b. Wakaf Produktif (waqf istitsmariy)

Wakaf produktif adalah wakaf yang hartanya ditujukan untuk penanaman modal dalam produksi barang-barang dan pelayanan yang dibolehkan syara' dalam bentuk apapun kemudian hasilnya diwakafkan sesuai keinginan pewakaf.

\section{Implikasi Wakaf Terhadap Perekonomian Indonesia}

Beberapa tahun ini wakaf yang massif dikembangkan dalam hal untuk membangun perekonomian bangsa adalah wakaf uang. Wakaf uang secara ringkas dapat dikatakan sebagai harta yang diwakafkan dalam bentuk uang. Wakaf uang sendiri memiliki banyak manfaat dalam penggunaannya. Wakaf uang sendiri merupakan gebrakan terbaru dalam hal perwakafan khususnya di Indonesia dan mampu mengambil peranan penting dalam merancang program-program pemberdayaan masyarakat (M. N. R. Al Arif, 2010).

Salah satu bentuk pelaksanaan dari wakaf uang adalah dalam bentuk investasi dimana, jika investasi menggunakan dana wakaf, hasil profit bersih invetasi itu akan dibagikan 90 persen untuk mauquf 'alaih dan 10 persen untuk 
nazhir. Wakif dapat menentukan penggunaan harta wakaf. Seperti untuk pendidikan, ekonomi, kesehatan, dan sosial. Untuk pendidikan contohnya seperti pembangunan sekolah gratis, bantuan biaya pendidikan, bantuan kebutuhan sekolah dan tunjangan guru. Dalam hal ekonomi contohnya dapat seperti pemberian bantuan modal usaha untuk UMKM serta program pendampingan seperti pelatihan dan pemasaran produknya. Selanjutnya bisa juga dilakukan dalam bentuk lainnya seperti layanan kesehatan, bantuan ibu hamil, bantuan melahirkan dan pengobatan gratis bagi masyarakat kurang mampu. Sedangkan untuk sosial dapat berupa pelatihan kerja untuk pengangguran, santunan anak yatim dan anak jalanan.

Salah satu bentuk bantuan modal usaha kepada UMKM dapat digunakan untuk meningkatkan daya produksi, sehingga perekonomian akan meningkat. Peningkatkan penerimaan negara akan meningkatkan dana pembangunan dan akan kembali akan berpengaruh dalam peningkatan pendapatan wakif. Sedangkan bantuan selain ekonomi dapat meningkatkan daya beli masyarakat yang menerima bantuan dari dana wakaf sehingga hal ini akan berdampak pada meningkatnya konsumsi masyarakat. Jika tingkat konsumsi meningkat, tentu akan berdampak secara langsung terhadap perkonomian itu sendiri.

\section{SIMPULAN}

Wakaf merupakan instrumen keuangan sosial Islam yang memiliki efek ganda dalam perekonomian. Melalui pengelolaan yang baik dan optimal, wakaf dapat berkontribusi positif dalam mengembangkan pertumbuhan ekonomi. Hal ini dapat diwujudkan dengan kontribusi wakaf dalam meningkatkan daya beli masyarakat. Selain itu, wakaf juga menjadi penopang pembiayaan negara dalam membiayai pembangunan dan infrastruktur. Dengan demikian, wakaf dapat berperan langsung dalam pembangunan nasional. Hal ini juga sebagaimana yang telah dipraktekkan oleh Rasulullah SAW beserta para sahabat dan khalifah setelahnya.

Berdasarkan penjabaran tersebut, penulis merekomendasikan agar para nazhir wakaf dapat meningkatkan kompetensi pengelolaan wakaf. Sehingga aset wakaf akan tumbuh dan berkembang lebih produktif, dan lebih optimal dalam memberikan manfaat dan maslahat kepada masyarakat luas.

\section{DAFTAR PUSTAKA}

Abdussalām, A. bin S. (n.d.). Tārikh al-Waqf 'inda al-Muslimīn wa Ghairihim. 2009. Al-Asqalāni, A. bin A. bin H. (1960). Fathu al-Bāri bi Syarh Shahīh al-Imām Abi 'Abdillah Muhammad bin Ismail al-Bukhāri. Juz 6.

Al-Bāqi, M. F. A. (1978). Al-Jāmi' al-Shahīh wa Huwa Sunanu al-Tirmīdzi. Juz 5, Cet. 2. 
Al-Ghani, M. I. A. (1999). Al-Masājid al-Atsariyah fi alMadīnah al-Nabawiyyah. Cet. 2.

Al-Hujaili, A. bin M. bin S. (1999). Al-Auqāf al-Nabawiyyah wa Waqfiyāt ba'dhi alShahābah al-Kirām: Dirāsah Fiqhiyyah, Tārīkhiyyah, wa Tstāiqiyyah. Nadwah al-Maktabah al-Waqfiyyah fi alMamlakah al-'Arabiyyah al-Su'udiyyah, 25-27 Muharram 1420.

Al-Khilāl, A. bin M. bin H. (1989). Kitābu al-Wukūf min Masāili al-Imām Ahmad bin Hambal al-Syaibāni. Cet. 1. Maktabah al-Ma'ārif.

Al-Mawardi, A. H. A. (1996). Economic Philosophy of Al-Mawardi: Economic Behavior in Adab Al-Dunya Wa-Al-Din and Al-Ahkam Al-Sulthaniyah. Dar alFikr.

Al-Sayyid, 'Izzat 'Ubaid al-Da'ās wa 'Ādil. (1968). Sunanu Abi Daud. Juz 3, Cet. 1.

Arif, M. N. R. Al. (2010). PEMBERDAYAAN MASYARAKAT BERBASIS WAKAF UANG. Jurnal Asy-Syir'ah Fak.Syariah UIN Sunan Kalijaga Yogyakarta, 44, No.11.

Arif, S. (2010). Wakaf Tunai Sebagai Alternatif Mekanisme Redistribusi Keuangan Islam. 4. https://doi.org/10.20885/lariba.vol4.iss1.art6

Aziz, M. (2017). Peran Badan Wakaf Indonesia (BWI) Dalam Mengembangkan Prospek Wakaf Uang Di Indonesia. JES (Jurnal Ekonomi Syariah), 1(2), 188208. https://doi.org/10.30736/jes.v1i2.15

Chapra, U. (2000). Masa Depan IImu EKonomi; Sebuah Tinjauan Islam (I. A. Basri (ed.)). Gema Insani Perss dan Tazkia Institute.

Direktorat Pemberdayaan Wakaf. (2008). Data Luas dan Lokasi Tanah Wakaf Nasional Sampai Dengan Tahun 2008.

Fathoni, M. A. (2019). Manajemen Investasi Syariah. Salemba Diniyah.

Ghanim, I. al-B. (n.d.). al-Auqaf wa Siyasah Fi Misra. Dar al-Asyrku.

Ghuddah, A. al-F. A. (1986). Sunanu al-Nasāi. Juz 6.

Hasan, S. (2010). Wakaf Uang Dan Implementasinya Di Indonesia. Jurnal Syariah Dan Hukum, 2(2), 162-177. https://doi.org/10.18860/j-fsh.v2i2.2976

Hidayat, A. R. (2016). Peran Wakaf Dalam Perekonomian (Studi Wakaf Tunai Terhadap Pembangunan Ekonomi). Perisai : Islamic Banking and Finance Journal, 1(1). https://doi.org/10.21070/perisai.v1i1.232

Huda, N. (2012). Keuangan Publik Islami; Pendekatan Teoritis dan Sejarah. Jakarta Kencana.

Juhro, S. M., Syarifuddin, F., Sakin, A., \& Suryanti, E. T. (2019). Keuangan Publik dan Sosial Islam Teori dan Praktik (1st ed.). Rajawali Pers.

Karim, A. A. (2008). Sejarah Pemikiran Ekonomi Islam. Raja Grafindo Persada.

Khusaeri, K. (2015). Wakaf Produktif. Al-A'raf : Jurnal Pemikiran Islam Dan Filsafat, 12(1), 77. https://doi.org/10.22515/ajpif.v12i1.1185

Mahdi, M. S. J. T. th. (n.d.). Lamhāt min Tārīkh al-Waqf al-Islāmi hatta al-'Ashr alUtsmāni.

Majid, M. N. (2003). Pemikiran Ekonomi Islam Abu Yusuf; Relevansinya Dengan Ekonomi Kekinian,. Pusat Studi Ekonomi Islam.

Muhtar, A. (2015). Potensi Wakaf Menjadi Lembaga Keuangan Publik (Kajian Kritis terhadap Konsep dan Praktik Wakaf dalam Hukum Islam). Asy-Syari'ah, 17(May), 9-18. 
Rahman, M. F. (2009). Wakaf Dalam Islam. Al-lqtishad: Jurnal Ilmu Ekonomi Syariah, 1(1). https://doi.org/10.15408/aiq.v1i1.2455

Riza Prima Hendra. (2003). Kemiskinan dan Kemandirian: Catatan Perjalanan dan Refleksi Bina Swadaya. Yayasan Bina Swadaya.

Rohim, A. N. (2018). Maximizing Utility And Distributing Income Equitably : Islamic Economics Journal, 4(2), 155-180.

Sancoyowati, F. (2018). Wakaf Sebagai Instrumen Kebijakan Pemerintah Untuk Mengatasi Eksternalitas Barang Publik (Perspektif Maqashid Syari'Ah). EI Dinar, 5(2), 7. https://doi.org/10.18860/ed.v5i2.5236

Syakir, A. (2016). Wakaf Produktif. Jurnal UIN Sumatera Utara.

Usman, S. (1999). Hukum Perwakafan di Indonesia. Darul Ulum Press. 